\title{
Poetic Deception: The Ujigawa Senjin Episode Between Court and Warrior Traditions
}

\author{
Naama EISENSTEIN*
}

\begin{abstract}
The story of Kajiwara Kagesue and Sasaki Takatsuna's race across the River Uji is one of the most commonly depicted episodes from the Heike monogatari. During the Tokugawa period this tale of deception and wit was presented in a wide variety of formats, yet the context in which these art works were made differed greatly from the original twelfth-century setting of the story. This article examines how the meaning of the Ujigawa senjin episode changed over time and suggests that its immense popularity in Tokugawa imagery was based more on its ability to fit with poetic associations than its content as a war story.
\end{abstract}

Keywords: Genpei war, Heike monogatari, Tokugawa art, Uji, warrior ideals

\section{Poetična prevara: zgodba Ujigawa senjin med dvorno in bojevniško tradicijo Izvleček}

Ena najbolj priljubljenih zgodb v Heike monogatari je, kako sta Kajiwara Kagesue in Sasaki Takatsuna tekmovala pri prečkanju reke Uji. V tokugavskem obdobju je bila ta zgodba o prevari in iznajdljivosti zelo priljubljena in se je pojavljala v številnih oblikah, pri čemer pa se je kontekst, v katerem so nastala ta umetniška dela, zelo razlikoval od prvotne različice iz 12. stoletja. Članek proučuje, kako se je pomen zgodbe Ujigawa senjin sčasoma spremenil, in ugotavlja, da njena velika priljubljenost $\mathrm{v}$ tokugavskem imaginariju temelji na njeni zmožnosti prilagajanja poetičnim asociacijam, ne pa na njeni vojni vsebini.

Ključne besede: vojna Genpei, Heike monogatari, tokugavska umetnost, Uji, bojevniški ideali

Naama EISENSTEIN, PhD Student,

SOAS University of London, Art and Archaeology, UK.

ne13[at]soas.ac.uk.

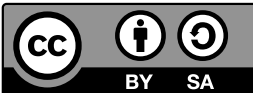




\section{Introduction}

Late in the first month of 1184 the River Uji, known for its ferocious current, was teeming with warriors. ${ }^{1}$ The famous bridge crossing the river was stripped of its planks in an attempt to stop the charging force, but this only succeeded in slowing it, as hundreds of armoured men advanced towards the water, on horseback or foot. From this mass of activity two figures stood out, pushing their horses forward, determined to win the honour of being the first on the battlefield. They were Kajiwara Genda Kagesue (梶原源太景季, 1162-1200) and Sasaki Shirō Takatsuna (佐々 木四郎高綱, ?-1214). As they separated from the crowd it was clear that Kagesue was in the lead, but then Takatsuna called out to him: "This is the biggest river in the west. Your saddle-girth looks loose, tighten it up!" (McCullough 1988, 287). ${ }^{2}$ Kagesue stopped his mount, quickly realising that he has been deceived—the girth was fine, but it was too late and he already lost his lead. Soon Takatsuna stood on the other bank, declaring in a mighty voice that he was the first to cross the River $\mathrm{Uji}$, and was written down in history as the first on the battlefield.

This seemingly simple story presents something of a riddle for the contemporary reader. How could Takatsuna win the honour of being the first on the battlefield when he used dishonourable methods to gain it? The straightforward answer lies in the changing perspectives of what is considered "honourable", a topic that has already been discussed by several scholars. ${ }^{3}$ But this episode, usually known as $U j i-$ gawa senjin (宇治川先陣), presents another riddle. ${ }^{4}$ It is one of the most prevalent images coming out of the Genpei War (源平合戦, 1180-1185) and during the Tokugawa period (also called the Edo period, 江戸時代, 1603-1868) it was depicted in a remarkably wide variety of formats. These include both elite ones such as folded screens (屏風) and illustrated handscrolls (絵巻), as well as popular formats

1 In the traditional Japanese dating system this battle occurred on the first month of the third year of the Juei (寿永) era. Official records do not state the exact day of the crossing of the River Uji, yet the Azuma kagami specifies the twentieth of the month as the day Noriyori (源範頼, ?-1193) and Yoshitsune (源義経, 1159-1189) entered the capital, as well as the day Kiso Yoshinaka (木曾義仲, 1154-1184) was killed, therefore it can be assumed that the Seta-Uji battle occurred on the same day. (Masamune 1926, 102)

2 The Japanese reads: 「此河は西国一の大河ぞや。腹帯ののびて見えさうは。しめ給へ」 (Ichiko 1973, 184).

3 The notion of honour in Japanese warrior culture and its change over time has been discussed by several scholars, including John W. Hall, Jeffrey Mass, Cameron Hurst, Karl Friday and Oleg Benesch.

4 Ujigawa senjin is the title of this episode in the Kakuichi-bon of the Heike monogatari variant, other variants use different titles. However, the Kakuichi-bon title became widespread already in Tokugawa times as it often appears on prints depicting this story. There are several English translations of the Kakuichi-bon that offer slightly different variations of the title, but to avoid confusion I chose to use transliteration of the Japanese. 
such as woodblock printed picture prints, commonly called ukiyo-e (浮世絵), and illustrated books (絵本). The immense popularity of Ujigawa senjin in Tokugawa material culture begs explanation. Genpei war tales were more than history by Tokugawa times, they were part of an intricate web of cultural meanings and imagery. This allowed Genpei stories like Ujigawa senjin to be used in various ways and by various groups in society. This paper is part of a wider research, and offers only a few considerations with a focus on elite art. I suggest that for the warrior elites of Tokugawa times Ujigawa senjin offered a unique mix of warrior and courtly associations that fit well with their self-image of warriors in peaceful times. ${ }^{5}$

\section{Ujigarwa senjin: Background and Sources}

Genpei war tales come to us in numerous versions. To begin with, the Heike monogatari (平家物語) that famously chronicles the war has close to a hundred variants that differ in length, detail and approach (Oyler 2006, 1-2). The best known of the variants today is the Kakuichi-bon (覚一本), named after its assumed composer, Akashi Kakuichi (明石覚一, c.1300-1371), a blind reciter of the Heike monogatari that had his own-immensely successful-version of the tale written down before his death. The Kakuichi-bon was meant for oral recitation and is thus relatively short and more stylised than other variants. The longest variant, the Genpei josuiki (源平盛衰記), includes far more detail and often offers additional insight to the characters' opinions and motivations (Oyler 2006, 14-16). Both the Kakuichi-bon and the Genpei josuiki were published in print in the early seventeenth century, making them available to readers of all social strata (Watson 1993, 17; Gunji 2017, 5-6). More importantly for this study, both variants have affected the iconography of Genpei images, or Genpei-e (源平絵), making them particularly relevant for the research of Genpei art. ${ }^{6}$ The majority of the frequently painted Genpei stories also have famous adaptations to the stage. Ujigawa senjin stands out as a popular image that does not have a source in drama, accentuating the importance of Heike monogatari variants as its source. ${ }^{7}$

5 This paper is part of my doctoral degree research and an earlier version of it was presented in the Bushidō in Transformation: Japanese Warrior Culture and Martiality conference organised by the Department of Asian Studies, Faculty of Arts, University of Ljubljana, 25-26 August 2017. I would like to thank the organisers for the wonderful opportunity to share some of my ideas.

6 For example, many depictions of the race show Kagesue holding his bow in his mouth to free his hands while retying his girth. This detail is unique to the Genpei jōsuiki, making it an undoubtful source for Genpei iconography.

7 There is only one $n \bar{o}$ play (謡曲) that relates to Ujigawa senjin in any way. Titled Sasaki (佐々 木), this play focuses on Takatsuna's interview with Yoritomo before setting out to battle and his confrontation with Kagesue. The concluding lines describe Takatsuna's victory but add nothing to the visual description of the race. The text of the play can be found in Chishin 1911, 178-81. 
Visualisations of the Ujigawa senjin episode focus on the river crossing, usually showing Takatsuna and Kagesue galloping toward the river or already in midstream, their horses immersed to their bellies (Fig. 1). As is often the case, textual descriptions of the story include much more detail. For one, the episode includes several more stories of warriors attempting to cross the river's current, yet depictions of those are rare, and the racing figures of Takatsuna and Kagesue are usually isolated from the greater battle scene that surrounded them. ${ }^{8}$ More importantly to the understanding of Ujigawa senjin, however, is the background given in an earlier episode titled Ikezuki no sata (生ずきの沙汰). ${ }^{9}$



Figure 1: Depiction of Takatsuna and Kagesue racing from the Ujigawa senjin episode. Heike Monogatari Picture Scrolls (平家物語絵巻). Set of 36 scrolls, attributed to the Tosa School, mid-17th c., colour and gold on paper; H. $35.2 \mathrm{~cm}$, Hayashibara Museum of Art, Okayama, Japan.

8 Other stories included in the Ujigawa senjin episode are those of Hatakeyama no Shōji Jirō Shigetada (畠山の庄司次郎重忠, 1164-1205) and Ōkushi Jirō Shigechika (大串次郎重親, years unknown) in the Kakuichi-bon. Other variants, like the Genpei jōsuiki, also include a story of how Kumagai Naozane (熊谷直実, 1141-1207) and his son Naoie (熊谷直家, 1169-1221) tried to cross the bridge by walking its beams, among others.

9 The name Ikezuki is written differently in the assorted variants, usually 生ズキ, 生飡 or 池掬. The title Ikezuki no sata comes from the Kakuichi-bon but seems to have been less commonplace than Ujigawa senjin, and the story appears under different titles. It is interesting to note that in the Heike monogatari emaki set of scrolls held in the Hayashibara Museum, which follows the Kakuichi-bon structure, this story was combined with the Ujigawa senjin storyline under the title Ujigawa no koto (宇治川のこと). 
Ikezuki is the name of the horse ridden by Takatsuna in Ujigawa senjin, which belonged to Minamoto no Yoritomo (源頼朝, 1147-1199) and was famed as the best horse in the land. Before setting out to battle, both Takatsuna and Kagesue stopped in Kamakura to pay their respects to their lord, Yoritomo. Kagesue took this opportunity to request Ikezuki for the battle, but was refused and offered another celebrated steed, the black Surusumi (磨墨), instead. Kagesue's disappointment turned into rage when, upon arriving to the battlefield at Uji, he recognised the chestnut-coloured Ikezuki at the hands of Takatsuna. Humiliated and furious he confronted Takatsuna, planning to kill the man. But Kagesue's fury vanished as Takatsuna explained that Ikezuki was not a gift, that he stole the horse knowing full well that Yoritomo will refuse a request to lend it. Kagesue was pleased by this story, satisfied that their lord, Yoritomo, did not favour Takatsuna. However, the story of the theft was a lie, concocted by Takatsuna to avoid fighting Kagesue. The text makes clear that Yoritomo did bestow Takatsuna with Ikezuki, and even warned him that some hostility could occur because others wanted the horse (Ichiko 1973, 177-82; McCullough 1988, 282-6; Mizuhara 1989, 272-3).

Kagesue's visit to Yoritomo and his confrontation with Takatsuna are often added to the depiction of the Ujigawa senjin chapter in formats such as handscrolls and painting albums (画帖) that allow multiple images for each chapter. The choice to illustrate this information, and not the stories of other warriors crossing the river, was probably made because the visit and confrontation scenes are the background of the iconic race scene, thus creating a more complete visual setting for the episode. At the same time, this choice highlights the importance of Takatsuna's and Kagesue's story. The choice to focus on the Takatsuna-Kagesue storyline is especially clear in elite art formats, while woodblock prints often include other episodes instead. A good example is illustrated printed books, which were sometimes structured similarly to picture scrolls with several images for each episode. Other illustrated books included only one image for each chapter, and condensed in it much more of the activity described in the text (Fig. 2). Ukiyo-e picture prints mostly follow the second option and show a combination of storylines. Thus, printed illustrations of Ujigawa senjin seem more interested in conveying the chaos and vigour of war than any specific storyline, while elite depictions of the episode clearly focus on Takatsuna and Kagesue.

The Genpei josuikis version of Takatsuna and Kagesue's story expands on the men's visits to Yoritomo, but does not offer much more explanation as to why Yoritomo gave Ikezuki to Takatsuna. Both men are deemed worthy of the horse in Yoritomo's eyes. Indeed, he considers Kagesue's request favourably and only refuses because many have already asked for Ikezuki and he worries that gifting 
the horse could cause disputes. Yet when Takatsuna is in need of a horse Yoritomo gives Ikezuki away after all. ${ }^{10}$ Perhaps because Yoritomo's favour is clear Takatsuna leaves with a promise to show his worth by being the first to cross the River Uji.

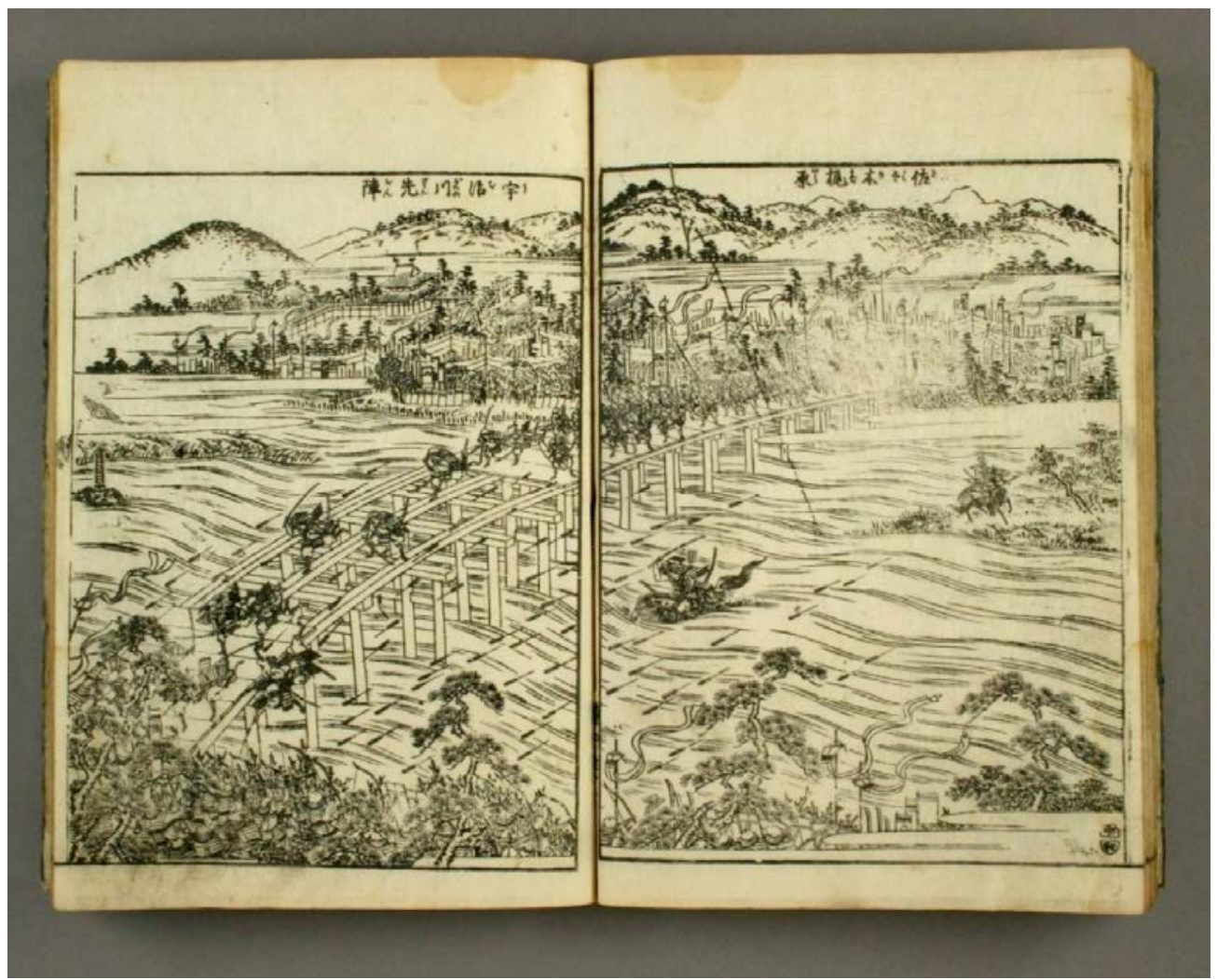

Figure 2: This depiction of the Ujigawa senjin story shows Takatsuna and Kagesue on the right page, but includes other storylines from the episode. Genpei Jösuiki zue (源平盛衰記図会), Akisato Rito (秋里篗島), Nishimura Chuwa (西村中和) and Oku Bunmei (奥文鳴), 1843, Set of six illustrated books, Waseda University.

10 In the Genpei josuiki Yoritomo mentions Kagesue specifically, as well as his brother Minamoto no Noriyori, as men who requested Ikezuki and could be angered by Takatsuna's possession of the horse. (Mizuhara 1988, 270-4). The Kakuichi-bon does not offer a reason for Yoritomo's sudden agreement to give Ikezuki away, but the Genpei josuiki seems to imply that he simply did not have any other good horse to give. One variant that does give a reason for Yoritomo's favouritism is the Engyo-bon (延慶本), in which a brash and discourteous Kagesue is contrasted with a polite and filial Takatsuna. See Franks 2009, 54-86. 
He even goes as far as saying that only death will stop him from being first (Ichiko 1975, 179; McCullough 1988, 284; Mizuhara 1989, 273). It is this promise that makes his competition with Kagesue a matter of life and death, and perhaps even more important at the time, a matter of honour.

\section{Deception in the Name of Honour}

A warrior's honour and reputation were his most prised possessions in pre-modern Japan. Gaining repute was not only for oneself, it passed down the family line, granting one's descendants status and often monetary rewards. In the same way, a tarnished name could harm a family for generations. The main currency for a warrior's reputation was success on the battlefield, and while numerous stories tell how warriors willingly sacrificed themselves to gain fame, just as many tell of those fighting tooth and nail to live to tell the tale. After all, reputation cannot be made without witnesses (Friday 2009, 56-58). The Ujigawa senjin story does not include a battle to the death, but Takatsuna would have considered it a great shame to lose, especially given his promise to Yoritomo, and was thus willing to use any means to achieve victory. The use of deception in a battle of honour may seems contradictory, but the notion of honour is a rather ambiguous one and differs over time and between cultures.

Medieval Japanese war tales show that deception was an acceptable means on the battlefield. From warriors donning women's clothing to escape death to hiding the small numbers of your force by creating a racket, there are ample examples of deception on the battlefield. The term damashi-uchi (だまし討ち), which translates as "striking down by deception" or "deception kill," is often used for one-on-one confrontations that demonstrate the use of wit to win. There was no dishonour in distracting your foe in order to kill him, quite the contrary, the victim of the deception was criticized for not being on his guard while the victor was hailed for quick wit and resourcefulness (Saeki 2004, 14-29; Franks 2009, 62). Ujigawa senjin is an example of deception on the battlefield and fits with the logic of damashi$u c h i$, but it is certainly not its most straightforward example.

The best known example of damashi-uchi is probably the story of Taira no Moritoshi, also known as Etchū no Zenji (平盛俊, 越中前司, ? -1184), which took place in 1184 during the aftermath of the Battle of Ichinotani (一の谷の戦い). The Taira fort in Ichinotani was burned and the the Taira were escaping to their boats, chased by Minamoto warriors searching for glory. Inomata no Koheiroku Noritsuna (猪俣小平六則綱, ? -1192), who fought on the Minamoto side, rode to attack Moritoshi, tackled him and they fell to the ground. Both men were strong, but Moritoshi was stronger and succeeded in pinning Noritusna down. 
Moritoshi was ready to make the final strike when Noritsuna called him out, saying that without an exchange of names the killing would be worthless. Moritoshi relented, and the two introduced themselves. Noritsuna then continued to suggest that Moritoshi surrendered, the Taira were lost but he, Noritsuna, could help Moritoshi and recommend him to the Minamoto leaders. Moritoshi was reluctant, but was finally convinced to accept the offer and the two sat down by a rice paddy. As they rested, another Minamoto warrior approached. Moritoshi tried to keep an eye on both Noritsuna and the new arrival, but Noritsuna used a moment of distraction, attacked and killed Moritoshi (Ichiko 1975, 238-41; McCullough 1988, 312-3; Mizuhara 1991, 77-80). Moritoshi's story is a perfect example of damashi-uchi. Noritsuna was not as strong or skilled a warrior as Moritoshi, but managed to turn the situation by outwitting him.

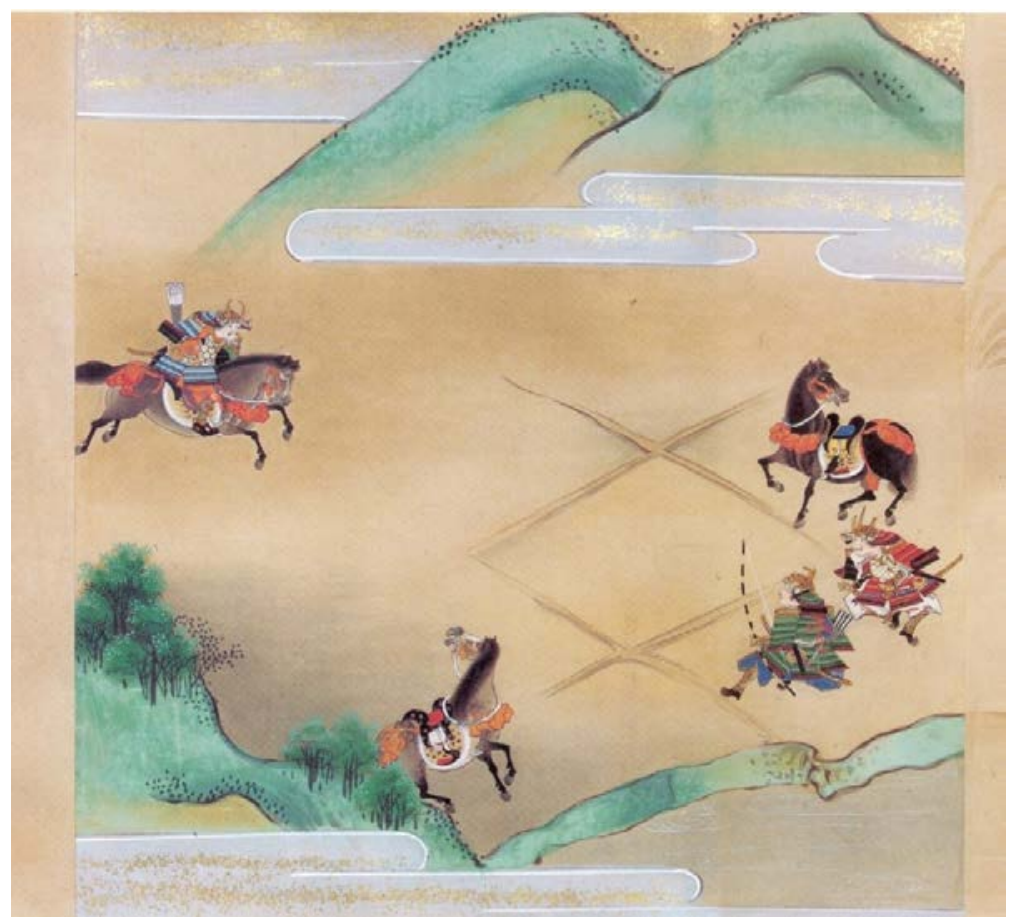

Figure 3: Noritsuna and Moritoshi resting by the rice paddy, Noritsuna is already moving to attack the unsuspecting Moritoshi. Heike Monogatari Picture Scrolls, Hayashibara Museum of Art, Okayama, Japan.

The story of Moritoshi's death is a very well-known episode, and is depicted in Genpei art. The iconic image of this scene shows the two warriors sitting by the 
rice paddy, a moment before Noritsuna's attack (Fig. 3). There are quite a few depictions of this story, although they do not stand on their own. Moritoshi's story appears in handscrolls, albums and battle screens of Ichinotani, but it is not found as the solitary topic of an artwork. This is very clear in elite works, but even in printed popular art Moritoshi's tale is uncommon. It appears in illustrated books of Heike monogatari and Genpei josuiki, as well as some painting manuals and collections of warrior images, but it is very rarely the topic of a picture print. ${ }^{11} \mathrm{In}$ fact, I only found one example, an 1857 print by Utagawa Kuniyoshi (歌川国芳, 1797-1861) that shows the two men's struggle (Fig. 4). ${ }^{12}$ This print, however, is not a standalone image. It is from a thematic series titled Heroes Matched to Five Colours (英勇五色合). Moreover, the image does not include a textual description of the story, and because the common iconography is not used the characters are only recognised by the name cartouches. However, considering how rare depictions of this story were, the lack of explanatory text suggests that it was known.

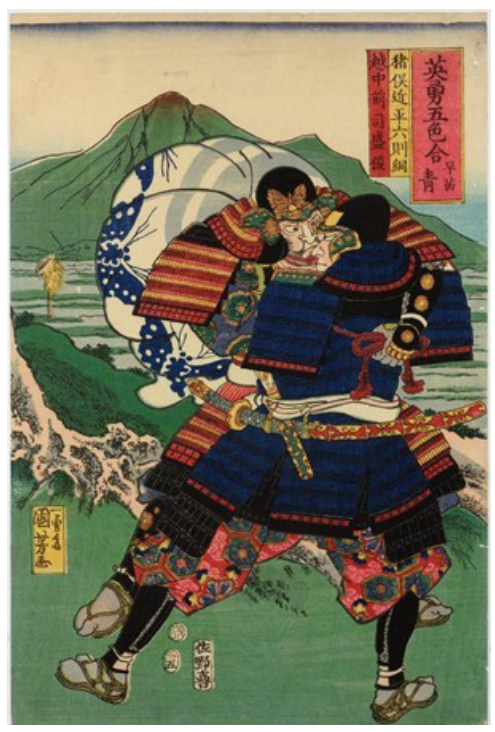

Figure 4: Blue: Inomata no Koheiroku Noritsuna, Etchu no Zenji Moritoshi from the series $\mathrm{He}$ roes Matched to Five Colours. Utagawa Kuniyoshi, 1857, multicoloured woodblock print, öban tate-e. The British Museum Collection, gift of Prof. Arthur R. Miller to the American Friends of the British Museum. Photograph (C) The British Museum

11 The appearance of Moritoshi's story in painting manuals is interesting considering the relative rarity of the image. Jenny Preston suggests that the scene was often used with no relation to the original context, instead building on the general familiarity with the story for puns and for conveying socio-political messages (Preston 2013, 163-71).

12 Since Moritoshi and Noritsuna were well-known figures, their names are included in some Genpei War picture prints that depict other scenes, but their confrontation is not painted. 
This in turn implies that its unpopularity in visual art was not based in the unpopularity of the story itself, but perhaps in its message, which by Tokugawa times was seen as problematic.

What we call damashi-uchi springs from the experience of war and the realities of the battlefield. Winning and surviving the battles were important, and when a warrior presented the head of his defeated foe it is doubtful that his methods were questioned. ${ }^{13}$ However, as the battles of the sixteen-century faded into the Tokugawa period, new ideas regarding appropriate warrior conduct formed. These ideas were based on ideals rather than on experience, and tended to be far more fixed and in a way deadlier.

Death on the battlefield was now hailed as heroic, especially at the hands of a worthy foe, and while damashi-uchi was still accepted as a battle strategy it was no longer admired. The use of deception on the battlefield was now considered shaming, but the fact that it was still discussed kept the option open. For example, an anonymous text from the early Edo period, titled Annotations to Heike monogatari (平家物語抄), praises Noritsuna's resourcefulness but also cautions that such tactic brings shame that will last for generations (Saeki 2004, 176). It is probable that in the minds of many Tokugawa warriors Noritsuna should have accepted death at the hands of the famed Moritoshi. This change in perspective might be the reason for the low number of visualisations of this scene. However, if indeed deception was no longer accepted as battle conduct, the popularity of the Ujigawa senjin episode is curious. On the one hand, it could be claimed that Takatsuna's deceit was not as immoral as Noritsuna's, since it did not lead to death. But on the other, resorting to trickery in a competition against your ally could be deemed even lower. Since deception was no longer an admired battlefield strategy in Tokugawa times, Ujigawa senjin had to offer more than this controversial discussion to be so widespread. I would like to suggest that the popularity of the scene had less to do with the story of the race itself, and more with details around it.

\section{The River Uji and the Lord of Kamakura}

One possible reason for the popularity of Ujigawa senjin is Takatsuna's promise to Yoritomo that he would win the race. Heike monogatari variants show this promise in different light, in the Genpei josuiki Takatsuna seems genuinely touched by his lord's gift of Ikezuki and the promise a gut reaction, while in the Kakuichi-bon

13 It is possible that the idea of challenging a "worthy foe" was helpful in this aspect. Defeating a high rank or famed enemy was effective for receiving rewards, but can also be seen as a reason to use any means to win. 
Takatsuna's promise raises eyebrows, and some criticise it as boastful (Ichiko 1975, 179; McCullough 1988, 284; Mizuhara 1989, 273-4). Either way, Takatsuna's promise to win the race across the River Uji creates a direct connection between him and his victory and Yoritomo, the high lord of Kamakura.

Yoritomo was the leader of the Minamoto during the Genpei War, but for the most part he was not on the battlefield. More concerned with establishing and stabilizing his warrior government in Kamakura, Yoritomo usually relied on his brothers, Noriyori (源範頼, ?-1193) and Yoshitsune (源義経, 1159-1189), to lead forces in battle. Therefore, very few of the examples of lord-retainer relationships and loyalty in Genpei stories mention Yoritomo, making Ujigawa senjin a rather rare example of a warrior acting in direct loyalty to Yoritomo. ${ }^{14}$ Considering that the Tokugawa, like preceding shogunal lines, related themselves to the first shogun, Yoritomo, Takatsuna's promise could certainly be a reason for the episode's popularity among warrior elites. ${ }^{15}$ However, not all audiences were necessarily interested in highlighting connections to the shogunate. Ujigawa senjin was a common topic in prints as well, and while popular art could not openly criticize the Tokugawa regime, it rarely endorsed it. Moreover, Yoritomo is only in the background of the story, especially since its iconic scene is the race itself and does not include Yoritomo. Indeed, some depictions of Ujigawa senjin include Yoshitsune as the field marshal of the battle, which greatly reduces the Yoritomo connection. Furthermore, there are several painting themes depicting Yoritomo directly, thus the connection with Yoritomo may have added to the popularity of Ujigawa senjin, but it is doubtful that it was the main reason for it.

Ujigawa senjin appears in a wide variety of formats, and, to my knowledge, is the only Genpei story to appear on lacquer writing boxes (Fig. 5). I have only seen three examples of writing boxes with an Ujigawa senjin theme, but even without assuming that more exist, the fact that this is the only Genpei scene to appear on writing boxes is intriguing. To begin with, writing boxes are not associated with warrior culture. Warriors owned them, of course, but being an item related

14 It should be noted that Yoshitsune is often described as loyal to Yoritomo, in Heike variants and in other texts. However, considering the bitter end of the brothers' relationship it would have been hard to use Yoshitsune as a model of loyalty to the Kamakura lord.

15 The importance of Takatsuna's promise to Yoritomo can be understood from an anecdote mentioned in the eighteenth-century Jōzan kidan (常山記談), written by Yuasa Jōzan (湯浅常山, 1708-1781). He describes how a warrior named Sano Fusatsuna (佐野房綱, 1558-1601) was moved to tears upon hearing a recitation of the Ujigawa senjin and Nasu no Yoichi episodes of the Heike Monogatari. When asked why he was so touched by these stories, both of which describe a battle of honour, Fusatsuna explained that it was Takatsuna's and Yoichi's determination to die if they could not fulfil their promises to their lord that moved him so (Yuasa and Suzuki 1965, 28-29; Gunji 2017, 7). 
to literary skills they were more associated with courtly traditions, and usually decorated with poetic themes. Secondly, the Heike monogatari includes numerous poems and mentions of poets that seem better related to literary traditions. The choice of Ujigawa senjin seems odd, except for the fact that the story took place in Uji.

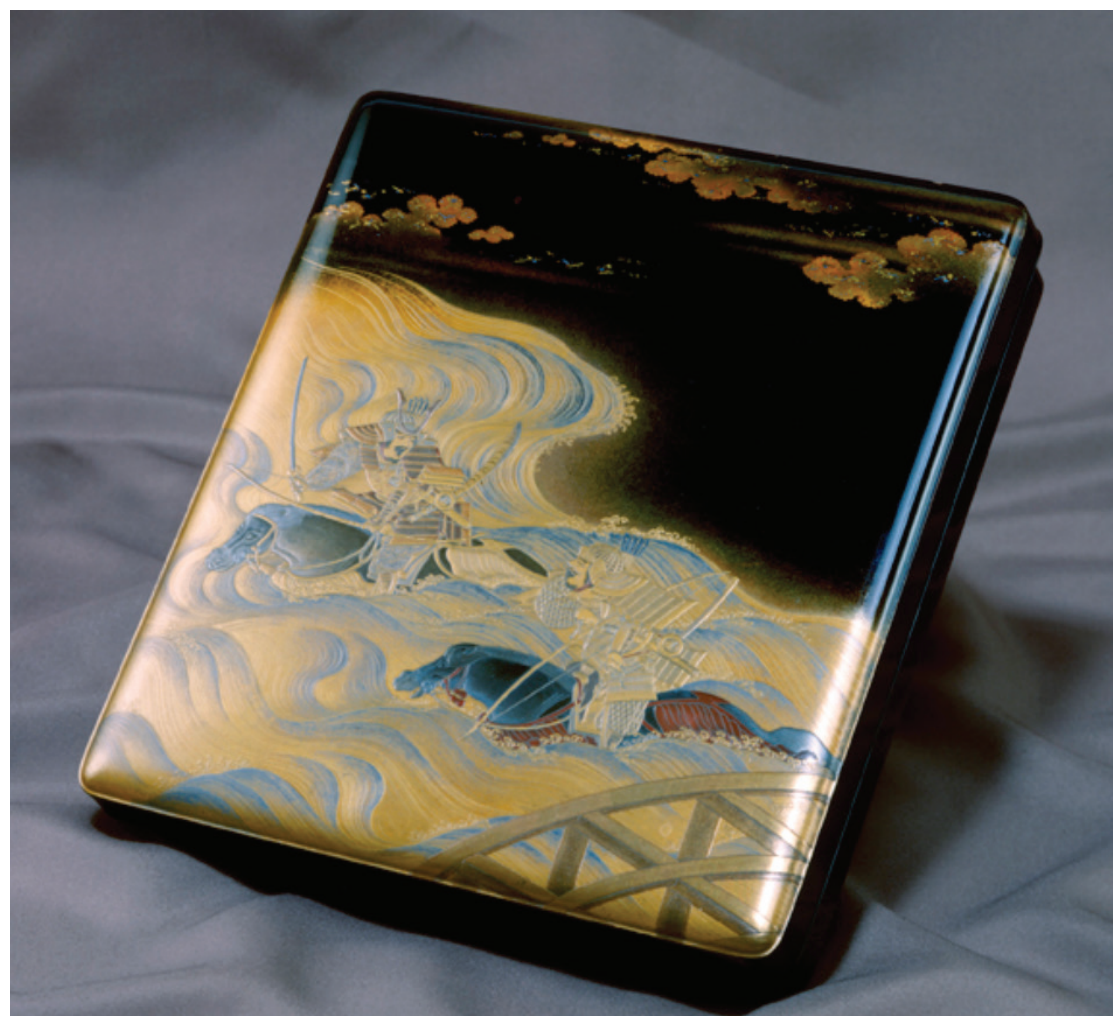

Figure 5: Suzuri-Bako (Writing Box), Iizuka Toyo and Chobei Tatsuke, 1700s, wood, lacquer, gold, silver, and stone; $20 \times 19 \mathrm{~cm}$. Denver Art Museum Collection, gift of Mr. and Mrs. George A. Argabrite, (1975.102.) Photograph (c) Denver Art Museum.

Uji is one of the earliest famous places, or meisho (名所), in Japan; it was mentioned in numerous poems and literary works, it was also one of the earliest Japanese meisho to be depicted in painting. ${ }^{16} \mathrm{Uji}$ had many associations, but in painting its first and foremost icon was the $\mathrm{Uji}_{\mathrm{j}}$ Bridge. The bridge was intricately

16 Before turning to local Japanese meisho, Japanese artists depicted Chinese famous places that had an important place in the Japanese poetic imagination. Uji is one of the earliest Japanese locations to be depicted as part of the development of the Yamato-e painting style. (Murase 2000, 202-3) 
connected through poetry with the image of women abandoned by their lovers, making weeping willows, whose long branches were associated with the tangled hair of an unkempt woman, its perfect companion. ${ }^{17}$ The fast current of the River Uji was associated with the turning of the wheel of the Dharma, which was marked in painting by the inclusion of a waterwheel (Screech 2000, 247). The Uji bridge became an utamakura (歌枕) and continued to be a popular theme over the years both in literary works and visual art. From the Momoyama period (桃山時代, 1573-1603) alone at least ten folding screens showing the bridge survive today, suggesting the existence of more examples (Munsterberg 1955, 107). ${ }^{18}$ The details and finishing of Momoyama Uji Bridge screens differ, but they generally include willows and a waterwheel (Fig. 6).

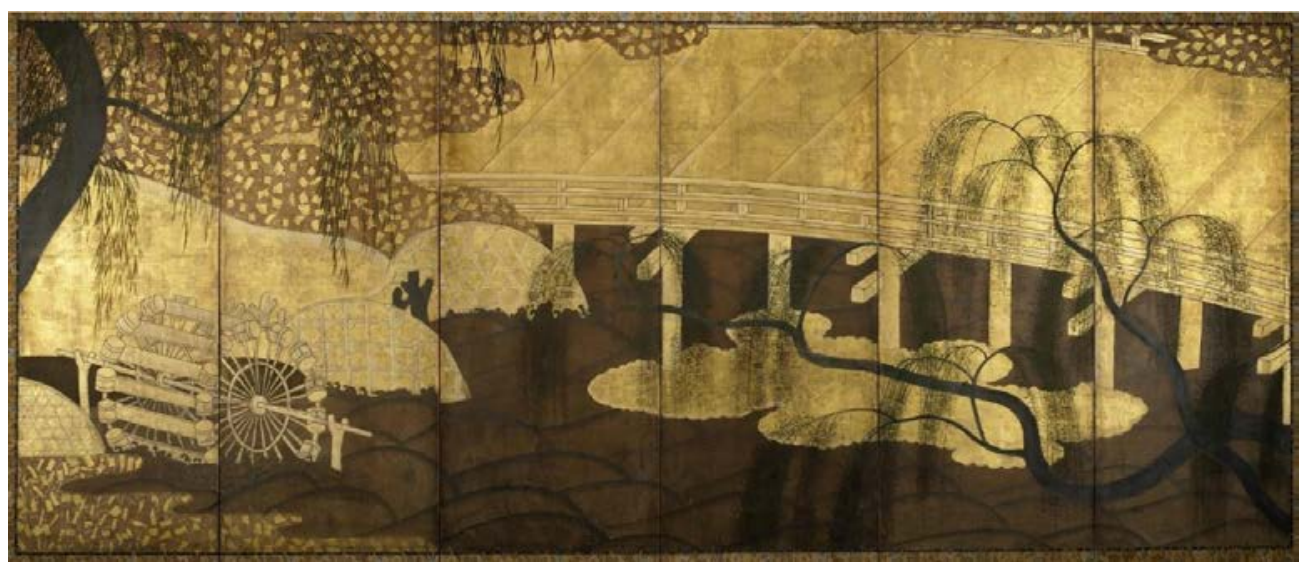

Figure 6: Willow Bridge and Water Wheel (Uji Bridge), left of a pair

Unknown artist, second half 16th century, Six-panel folding screen, ink, colour, gold, and silver on paper, $142.88 \times 335.76 \mathrm{~cm}$. Minneapolis Institute of Art, The Putnam Dana McMillan Fund and gift of funds from the Mary Livingston Griggs and Mary Griggs Burke Foundation (2004.178.1) Photograph (C) Minneapolis Institute of Art

17 The association of the River Uji and its bridge with women's plight in love was already well established in the Heian period (平安時代, 794-1180). The tenth-century Kokinwakash $\bar{u}$ (古 今和歌集) includes a poem describing a woman, known only as Hashihime (橋姫), the Lady of the Bridge, who awaited her lover with no avail. Uji and the Uji Bridge continued to appear in Genji monogatari (源氏物語) as backdrop to Lady Ukifune's suffering in love. (Shirane 1987, 156; Screech 2000, 247). Tangled and unkempt hair was a signifier of either a poor or abandoned woman in Heian literature. Well-kept hair was the symbol of a dignified court lady, while wild hair could symbolise the loss of social position, peace of mind or connection with society. For a discussion of the use of hair in the representation of women in mediaeval Japan see Pandey 2016.

18 The latest edition of Munsterberg's book, published 2011, still counts ten examples of Uji Bridge screens from the Momoyama. 




Figure 7: The Battle at Uji River, Anonymous, first half of the 17th century, single six-fold screen, colour on paper and gold leaf, $152.1 \times 349.4 \mathrm{~cm}$. Photograph (C) Victoria and Albert Museum

The fact that several battles took place at the Uji Bridge was usually kept separate from the place's poetic associations. Visual depictions thus tended to focus on either the poetic-literary tradition or war tales and battles. However, the placing of the Ujigawa senjin scene on a writing box connects the two threads in one object. An even clearer connection was made in an Ujigawa senjin folding screen held in the Victoria and Albert Museum (Fig. 7). At first glance this exquisite screen seems like other Ujigawa senjin depictions, with Takatsuna riding Ikezuki into the water and Kagesue on the black Surusumi trying to catch up. However, this screen includes elements of the poetic tradition of $\mathrm{Uji}$, a waterwheel in the right bottom corner and weeping willows planted at the base of the bridge. The bridge itself has the same compositional presence as in most Momoyama Uji Bridge screens, only that its planks have been removed, exposing the skeleton of its flowing form. The screen balances poetic and warrior traditions beautifully, melding them into one. Although we do not have information on the production of this screen, it is probable that its patron was a warrior that wanted to associate himself with court traditions. The dating of the screen to the first half of the seventeenth century fits with the attempt to combine the traditions, as warrior elites settled into the new peace and their new position in it.

The Victoria and Albert screen is a unique case, but it is plausible that the poetic association of $\mathrm{Uji}_{\mathrm{ji}}$ had contributed much to the popularity of Ujigawa senjin in early modern art. Other famous battles took place at Uji, but they were violent and perhaps not fitting with the new peace of Tokugawa. The relative 
light-heartedness of the Ujigawa senjin scene, showcasing a battle of wit instead of a battle to the death, made it more compatible for the amalgamation of poetic and warrior traditions. Takatsuna's conduct could be seen as dishonourable, but the promise he gave his lord, Yoritomo, made it acceptable. For the warrior elites of Tokugawa times Ujigawa senjin was a window to past glories of their class as well as a connection to the ever-important court traditions through the poetic associations of $\mathrm{Uji}$. Connecting warrior history and poetic tradition was a statement of the new self-image of warriors in Tokugawa times, strongly rooted in the history that gave their rule legitimacy, but also well educated and cultivated. Artworks depicting Ujigarwa senjin were an embodiment of this self-image and, as the number of extant folding screens that depict this scene suggest, proudly decorated the homes of numerous warriors.

\section{References}

Franks, Amy. 2009. "Another Tale of the Heike: An Examination of the Engyobon Heike monogatari." PhD diss., Yale University.

Friday, Karl. 2009. "What a Difference a Bow Makes: The Rules of War in Early Medieval Japan." In Currents in Medieval Japanese History: Essays in Honor of Jeffrey P. Mass, edited by Gordon Mark Berger, 53-86. California: Figueroa Press.

Chishin, Furuya, ed. 1911. Yōkyoku Zenshù 謡曲全集 (Complete Collection of Nō Plays) vol. 2. Tokyo: Kokumin Bunko Kankōkai.

Gunji, Naoko. 2017. "Heike Paintings in the Early Edo Period: Edification and Ideology for Elite Men and Women." Archives of Asian Art 67 (1), April: 1-24. Accessed October 25, 2017. https://doi.org/10.1215/00666637-3788627.

Ichiko, Teiji. 1973. Heike Monogatari 平家物語, Nihon koten bungaku zenshū 29 日本古典文学全集. Tokyo: Shōgakkan.

Masamune, Atsuo. 1926. Azuma kagami 吾妻鑑, Nihon koten zenshū 日本古典 全集30. Tokyo: Nihon koten zenshū sengyōkai.

McCullough, Helen Craig. 1988. The Tale of the Heike. California: Stanford University Press.

Mizuhara, Hajime. 1989. Shintei Genpei josuiki 新定源平盛衰記 (Rise and Fall of the Genji and Heike, New Edition), vol. 4. Tokyo: Shin Jinbutsu Ōraisha.

Mizuhara, Hajime. 1991. Shintei Genpei josuiki 新定源平盛衰記 (Rise and Fall of the Genji and Heike, New Edition), vol. 5. Tokyo: Shin Jinbutsu Ōraisha.

Munsterberg, Hugo. 1955. The Landscape Painting of China and Japan. Rutland, Vt.: C.E. Tuttle Co.

Oyler, Elizabeth. 2006. Swords, Oaths, and Prophetic Visions: Authoring Warrior Rule in Medieval Japan. Honolulu: University of Hawaii Press. 
Murase, Miyeko, and Mary Griggs Burke. 2000. Bridge of Dreams: The Mary Griggs Burke Collection of Japanese Art. New York: Metropolitan Museum of Art.

Pandey, Rajyashree. 2016. Perfumed Sleeves and Tangled Hair: Body, Woman, and Desire in Medieval Japanese Narratives. Honolulu: University of Hawai'i Press.

Preston, Jenny. 2013. "Intimations of War: Sukenobu's Warrior Imagery." In $A$ study of Nishikawa Sukenobu (Nishikawa Sukenobu wo yomu), edited by Aki Ishigami, 163-140. Kyoto: Ritsumeikan University Art Research Centre.

Saeki, Shin'ichi. 2004. Senjō no seishin shi: bushidō to iu genei 戦場の精神史一武 土道という幻影 (The History of Battlefield Principles: the Illusion of Bushido). Tokyo: NHK buksu.

Screech, Timon. 2000. The Shogun's Painted Culture: Fear and Creativity in the Japanese States, 1760-1829. London: Reaktion Books.

Shirane, Haruo. 1987. The Bridge of Dreams: A Poetics of the Tale of Genji. Stanford: Stanford University Press.

Watson, M. G. 1993. "WG Aston's Annotations to the Rufubon Heike Monogatari." Meiji Gakuin review, International E regional studies 11 (March): 17-59. Accessed November 10, 2017. http://hdl.handle.net/10723/1646.

Yuasa, Jōzan, and Tōzō Suzuki. 1965. Jōzan kidan 常山紀談. Tokyo: Kadokawa shoten. 